\title{
Andrographolide induces DNA damage in prostate cancer cells
}

\author{
Ingrid S. Forestier-Román ${ }^{1,2}$, Andrés López-Rivas ${ }^{2,3}$, María M. Sánchez-Vázquez², \\ Krizia Rohena-Rivera', ${ }^{1,2}$, Gretchen Nieves-Burgos ${ }^{2,3}$, Humberto Ortiz-Zuazaga ${ }^{4}$, \\ Carlos A. Torres-Ramos ${ }^{5}$ and Magaly Martínez-Ferrer ${ }^{2,6}$ \\ ${ }^{1}$ Department of Biochemistry, School of Medicine, University of Puerto Rico, San Juan, Puerto Rico, USA \\ ${ }^{2}$ University of Puerto Rico Comprehensive Cancer Center, Division of Cancer Biology, San Juan, Puerto Rico, USA \\ ${ }^{3}$ Department of Biology, University of Puerto Rico at Rio Piedras, San Juan, Puerto Rico, USA \\ ${ }^{4}$ Department of Computer Sciences, University of Puerto Rico at Rio Piedras, San Juan, Puerto Rico, USA \\ ${ }^{5}$ Department of Physiology, School of Medicine, University of Puerto Rico, San Juan, Puerto Rico, USA \\ ${ }^{6}$ Department of Pharmaceutical Sciences, School of Pharmacy, University of Puerto Rico, San Juan, Puerto Rico, USA \\ Correspondence to: Magaly Martínez-Ferrer, email: magaly.martinezl @upr.edu
}

Keywords: chemoprevention; phytochemicals; mouse model; DNA repair; gene expression

Received: March 28, $2017 \quad$ Accepted: January 09, $2019 \quad$ Published: February 01, 2019

Copyright: Forestier-Román et al. This is an open-access article distributed under the terms of the Creative Commons Attribution License 3.0 (CC BY 3.0), which permits unrestricted use, distribution, and reproduction in any medium, provided the original author and source are credited.

\section{ABSTRACT}

Prostate cancer ( $\mathrm{PCa}$ ) is the most common diagnosed cancer and is the third cause of cancer mortality in men in the USA. Andrographolide, a diterpenoid lactone isolated from Andrographis paniculata, has shown to possess anticarcinogenic activity in a variety of cancer cells. In this study, we examined the efficacy of Andrographolide in PCa using in vitro and in vivo models. Androgen-independent (PC3) and androgendependent (22RV1) cell lines were treated with Andrographolide to determine the effect in cell motility, cell proliferation and apoptosis. Andrographolide decreased PCa cell migration, decreased invasion, and increased cell apoptosis in vitro. Tumor growth was evaluated using an orthotopic xenograft model in which the prostates of SCID mice were injected with $22 \mathrm{RV1}$, and mice were treated three times per week with Andrographolide $10 \mathrm{mg} / \mathrm{kg}$. Andrographolide decreased tumor volume, MMP11 expression and blood vessels formation in vivo. Gene expression analysis identified cellular compromise, cell cycle, and "DNA recombination, replication and repair" as the major molecular and cellular functions altered in tumors treated with Andrographolide. Within DNA repair genes we confirmed increased expression of genes involved in DNA double strand break repair. Consistent with this observation we detected increased YH2AX in Andrographolide treated tumors and in cells in culture. Taken together, these data suggest that Andrographolide inhibits PCa by promoting DNA damage.

\section{INTRODUCTION}

Prostate cancer $(\mathrm{PCa})$ is the second most frequently diagnosed cancer in men, with 1.1 million new cases estimated in 2012 and was the fifth leading cause of cancer death in men worldwide in 2012 [1]. Currently, PCa is the most common cancer in men as well as one of the leading causes of cancer-related mortality in the United States [2]. According to the statistics, one out of five men will be diagnosed with prostate cancer [2]. Chemoprevention and prevention with phytochemicals has been widely studied in cancers such as lung, colon, breast and prostate cancer. The combination of natural products with the standard of care treatment is an emerging area of cancer therapeutics with a multitude of benefits such as dose reduction, synergistic effect and delay in development of drug resistance [3-5].

Andrographis paniculata is known to possess a variety of pharmacological activities [6-9]. The major component of this plant, Andrographolide, has 
been reported to have therapeutic potential against liver disorders, common cough and cold, infection, inflammation and cancer in humans [7, 8, 10-15]. For example, Andrographolide has been shown to inhibit cancer cell growth and its $50 \%$ growth inhibition ranges from 10 to $28 \mu \mathrm{M}$, depending on the type of cancer cell tested which includes the human cancer cell lines SW620 (colon cancer), A498 (renal cancer), NCI/ADR-RES (ovarian cancer), U251 (glioblastoma), HT29 (colorectal cancer), H522 (lung cancer), M14 (melanoma), SKOV3 (ovarian cancer) and DU145 (prostate cancer) [16]. On the other hand, recent reports showed that Andrographolide, at concentrations from 10 to $100 \mu \mathrm{M}$, could induce apoptosis in human prostatic adenocarcinoma PC-3 cells and human leukemic HL-60 cells [10, 17, 18]. Previous studies also demonstrate that Andrographolide possesses potent antiangiogenic activity and, since angiogenesis plays an important role in tumorigenesis, it could have potential therapeutic effects $[19,20]$.

It has been reported that other phytochemicals, such as curcumin, increase the protein levels of those associated with DNA damage and repair, such as O6methylguanine-DNA methyltransferase, BRCA1, mediator of DNA damage checkpoint 1, p-p53 and p-H2A.XSer140 in cancer cells, suggesting that this phytochemicals activate a DNA damage response [21, 22]. In this study, we evaluated the role of Andrographolide in prostate cancer using cellular and animal models. We show that Andrographolide decreased prostate cancer cell motility, decreased invasion, and increased apoptosis in vitro. In addition, Andrographolide decreased prostate tumor growth, decreased matrix metalloproteinase 11 (MMP11) expression, decreased angiogenesis and altered DNA repair genes such as BRCA2, ATM, BRIP1 in vivo. Furthermore, we suggest a possible mechanism of action through which Andrographolide inhibits cancer progression by modulating DNA repair genes. This is, to the best of our knowledge, the first study correlating Andrographolide with double strand DNA repair genes.

\section{RESULTS}

\section{Andrographolide suppresses proliferation of prostate cancer cells lines}

The anti-proliferative activity of Andrographolide was evaluated using human prostate cancer cell lines (PC3, 22RV1, LNCaP) and normal human prostate cells (RWPE1). Cells were treated with 10-25 $\mu \mathrm{M}$ Andrographolide for 12 hours, 24 hours and 48 hours. Cell viability was measured using the MTS assay. As shown in Figure 1A, Andrographolide inhibited the proliferation of $\mathrm{PC} 3,22 \mathrm{RV} 1$ and $\mathrm{LNCaP}$ in a dosedependent manner. When PC3 cells were treated with Andrographolide for 12 and 24 hours, there were no changes in proliferation (Supplementary Figures 1 and 2).
However, Andrographolide inhibited PC3 cell growth at 48 hours of treatment (Figure 1A). 22RV1 and LNCaP cells treated with Andrographolide for 12 hours did not show changes in proliferation (Supplementary Figures 3 and 4). However, Andrographolide inhibited cell proliferation of 22RV1 and LNCaP cells after 24 hours of treatment (Figure 1A). Accordingly, $\mathrm{GI}_{50}$ values of Andrographolide were determined for PC3, 22RV1 and LNCap cells as 26.2, 24.2 and 28.1 $\mu \mathrm{M}$, respectively (Figure 1B, 1C). In order to determine if Andrographolide was toxic to normal cells, we performed MTS Assay using RWPE1 cells. Andrographolide did not inhibit RWPE1 at the tested doses, therefore it is not toxic for normal human prostate cells.

\section{Andrographolide decreases the migration and invasion of prostate cancer cells}

We investigated the effect of Andrographolide on the migration ability of PC3 cells by using the woundhealing migration assay. For this, a confluent monolayer of PC3 cells were wounded and allowed to migrate for 12 hours and 24 hours (Figure 2A). At 12 and 24 hours, the migration of PC3 cells was significantly reduced by $10 \%$ and $15 \%$, respectively, in cells treated with Andrographolide $(25 \mu \mathrm{M})$ when compared to control $(P<0.05)$ (Figure 2B). PC3 cells treated with Andrographolide for 12 and 24 hours did not show a decreased in proliferation. Thus, the PC3 cells are presenting an inhibition of their migration ability and not due to changes in proliferation. 22RV1 cells were not used for migration assay because they do not grow in a confluent monolayer. Since Andrographolide has been found to inhibit cell invasion in other cancers, we decided to examine the effect of Andrographolide in cell invasion in prostate cancer using androgen-independent PC3. The assay was performed using the Boyden chamber assay for $12 \mathrm{~h}$ and $24 \mathrm{~h}$ of treatment. Results show that Andrographolide $(25 \mu \mathrm{M})$ reduced the invasion of PC3 cells by $50 \%$ after 12 hours and by $40 \%$ after 24 hours (Figure 2C, 2D). No significant decrease was observed in 22RV1 cell line (Supplementary Figure 5).

\section{Andrographolide promotes apoptosis in prostate cancer cells}

To evaluate whether the decrease in cell viability was also accompanied by an increase in apoptosis, we tested whether Andrographolide induces apoptosis in PC3 and 22RV1 prostate cancer cells. PC3 cells were treated with Andrographolide $(25 \mu \mathrm{M})$ for $24 \mathrm{~h}$ and $48 \mathrm{~h}$ followed by flow cytometry analysis for Annexin-V. A 50\% increase was observed in apoptotic cells after 48 hours of treatment in PC3 cells (Figure 3A). Furthermore, the activity of caspase 3/7 was measured by luminescence in PC3 and $22 \mathrm{RV} 1$ cells. After 24 hours of treatment, significantly increased activity of caspase 3/7 was observed in the PC 3 
cell line (Figure 3B). No significant increase was observed in 22RV1 cell line (Data not shown).

\section{Andrographolide inhibits cell cycle progression}

To evaluate viability and proliferation of PC3 cells, inhibition of cell cycle progression with $25 \mu \mathrm{M}$ Andrographolide was evaluated at 24 and 48 hours in PC3 cells using flow cytometry. PC3 cells treated with Andrographolide showed a significant decrease in cell number at G1/G0 phase after 48 hours of treatment and an increase of cell population at $\mathrm{G} 2 / \mathrm{M}$ phase after 48 hours of treatment. $(P<0.05)$. These results suggest a cell cycle arrest at $\mathrm{G} 2 / \mathrm{M}$ phase (Figure 3C). For this assay, 22RV1 cells were not evaluated because they grow in clusters.

\section{Andrographolide inhibits prostate tumor progression in SCID mice}

To test the effect of Andrographolide on prostate tumor progression, a SCID orthotopic model was used to develop tumors in the anterior prostate lobes using 22RV1 cells. One week following cell injection, mice were treated $3 \times$ per week, by intraperitoneal injections, with vehicle or $10 \mathrm{mg} / \mathrm{kg}$ Andrographolide for four weeks. Mice treated with Andrographolide $10 \mathrm{mg} / \mathrm{kg}$ developed smaller tumors when compared to control tumors. The tumors treated with
Andrographolide $10 \mathrm{mg} / \mathrm{kg}$ had three times lower tumor volume than control tumors (Figure 4A, 4B). Pathological, histological and immunohistochemical analyses of collected tumor tissue were used to study the effect of Andrographolide in tumor biology. Slides were examined by a pathologist at low, medium and high power under a compound light microscope. Tumor assessment was made as described by Isaacs and Hukku [23]. Tumors were classified in four categories by degree of differentiation: well differentiated, moderately differentiated, poorly differentiated, and anaplastic. Well differentiated tumors are characterized by the presence of glandular structures, lumen, basement membrane, and stroma. Moderately differentiated tumors are characterized by smaller glandular structures with the lumen obstructed by tumor cells. However, the basement membrane and stroma remained intact. Tumors classified as poorly differentiated have absence of glandular structures, basement membrane, and do not show a consistent relationship between tumor cells and stroma. Individual tumor cells, however, still show a normal nucleus to cytoplasm ratio. Tumors classified as anaplastic lack appearance of tissue organization and individual tumor cells show irregular nucleus size and abnormal nucleus to cytoplasm ratio. All tumor samples, regardless of the treatment, were classified as histologically anaplastic showing no significant differences among treatments (Figure 4C).

\section{A}
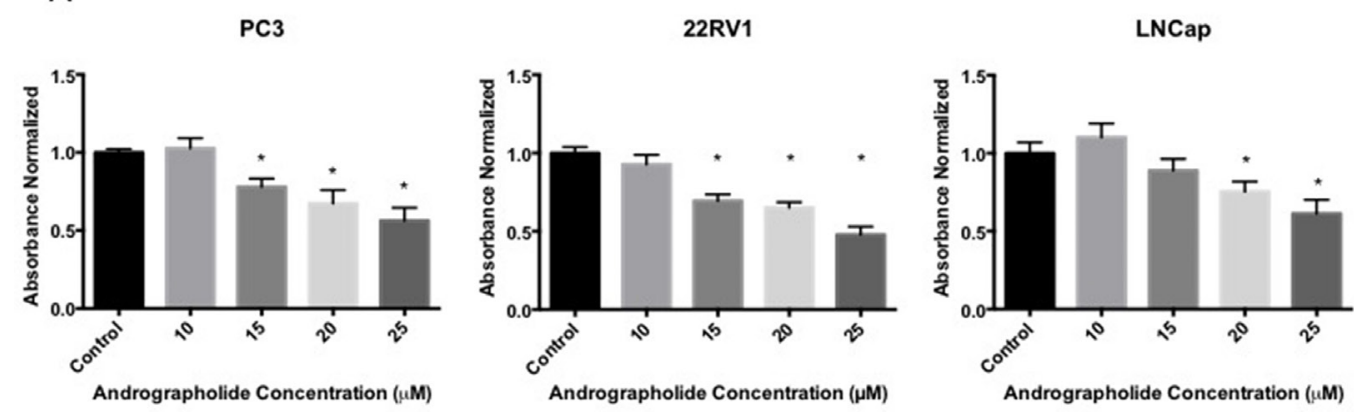

B

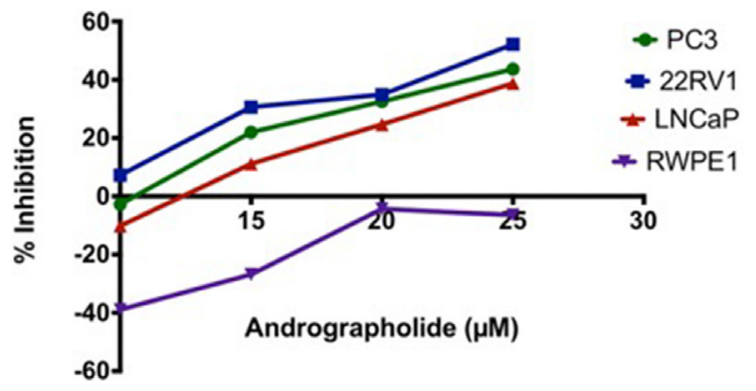

C

\begin{tabular}{c|c}
\hline Cell Line & $\mathrm{GI}_{\mathbf{5 0}}$ Calculated $(\mu \mathrm{M})$ \\
\hline PC3 & 26.23 \\
22RV1 & 24.24 \\
LNCaP & 28.06 \\
\hline
\end{tabular}

Figure 1: Andrographolide decreased cell viability in prostate cancer cells. Cells were incubated with Andrographolide at the indicated doses and cell viability was determined 24 hours or 48 hours after treatment. (A) Andrographolide inhibited PC3 cell growth after 48 hours; inhibited 22RV1 and LNCaP cell growth after 24 hours, but did not inhibited RWPE1 cell growth after 24 hours. (B) Percentage of cell inhibition was used to determine $\mathrm{GI}_{50}$ value. Experiments were made in triplicate. Statistical analysis was performed using one-way ANOVA, followed by Dunnett's test. Mean $+\operatorname{SEM}\left({ }^{*}=P<0.05\right.$ when compared to control). (C) GI ${ }_{50}$ was determined for each cell line. 


\section{Andrographolide decreases MMP11 expression proliferation and blood vessel formation in vivo}

The effect of Andrographolide on MMP11 was evaluated to determine if the expression of this protein, involved in the breakdown of extracellular matrix, was also affected by Andrographolide. For this, we performed an immunohistochemical assay. We found a decrease in MMP11 expression in treated tumors (Andrographolide $10 \mathrm{mg} / \mathrm{kg}$ ) when compared to control (Figure 4D). The expression of the proliferation markers pH3 and Ki-67 were evaluated to determine the effect of Andrographolide in this cancer hallmark. In this study, we found that Andrographolide decreased the expression of $\mathrm{pH} 3$ and $\mathrm{Ki}-67$ in mice tumors when compared to control (Figure 4E). Additionally, one of the cancer hallmarks, angiogenesis, is essential to cancer progression since the formation of new blood vessels helps tumors to grow. To test the effect of Andrographolide in the formation of blood vessels, the expression of CD31 was measured by immunofluorescence. In our study decreased formation of blood vessels in tumors from mice treated with $10 \mathrm{mg} / \mathrm{kg}$ Andrographolide was observed compared to those treated with control (Figure 5).

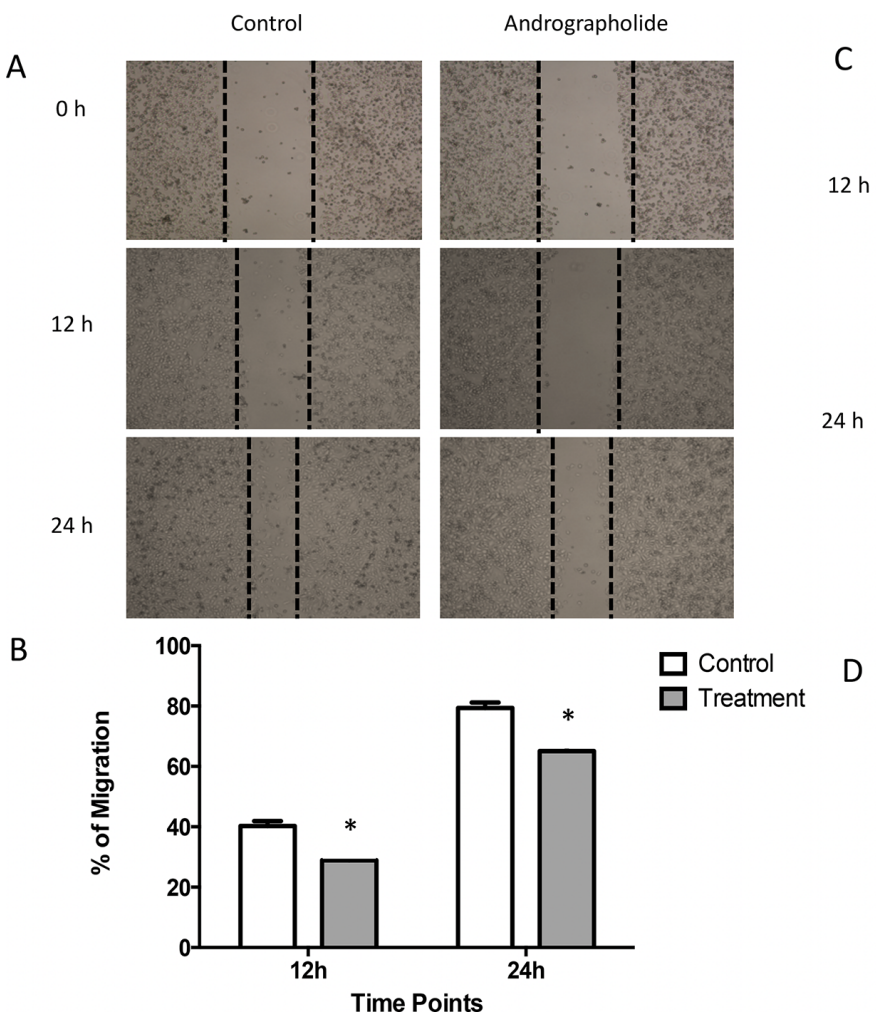

\section{Andrographolide alters genes associated with cellular compromise, cell cycle, and DNA recombination, replication and repair}

Microarray analysis was performed using mice tumor samples to identify the effect of Andrographolide $10 \mathrm{mg} / \mathrm{kg}$ on gene expression. Andrographolide $10 \mathrm{mg} / \mathrm{kg}$ treatment significantly altered the expression of 675 genes classified in three broad molecular and cellular functions: cellular compromise, cell cycle, and "DNA recombination, replication and repair". Among the DNA recombination, replication and repair category, the following genes were represented: ATM serine/threonine kinase (ATM), Bloom syndrome, RecQ helicase like (BLM), Breast cancer 2 , early onset (BRCA2), BRCA1 interacting protein C-terminal helicase 1(BRIP1), Claspin (CLSPN), Nibrin (NBN), and partner and localizer of BRCA2 (PALB2) (Table 1). A common feature of these genes is that they are associated with the double-strand break repair pathway. To validate that the expression of this group of genes is affected by Andrographolide, we performed real time PCR assays. We observed an increased in the expression of double strand break repairs genes: ATM serine/threonine kinase (ATM), Bloom syndrome, RecQ helicase like

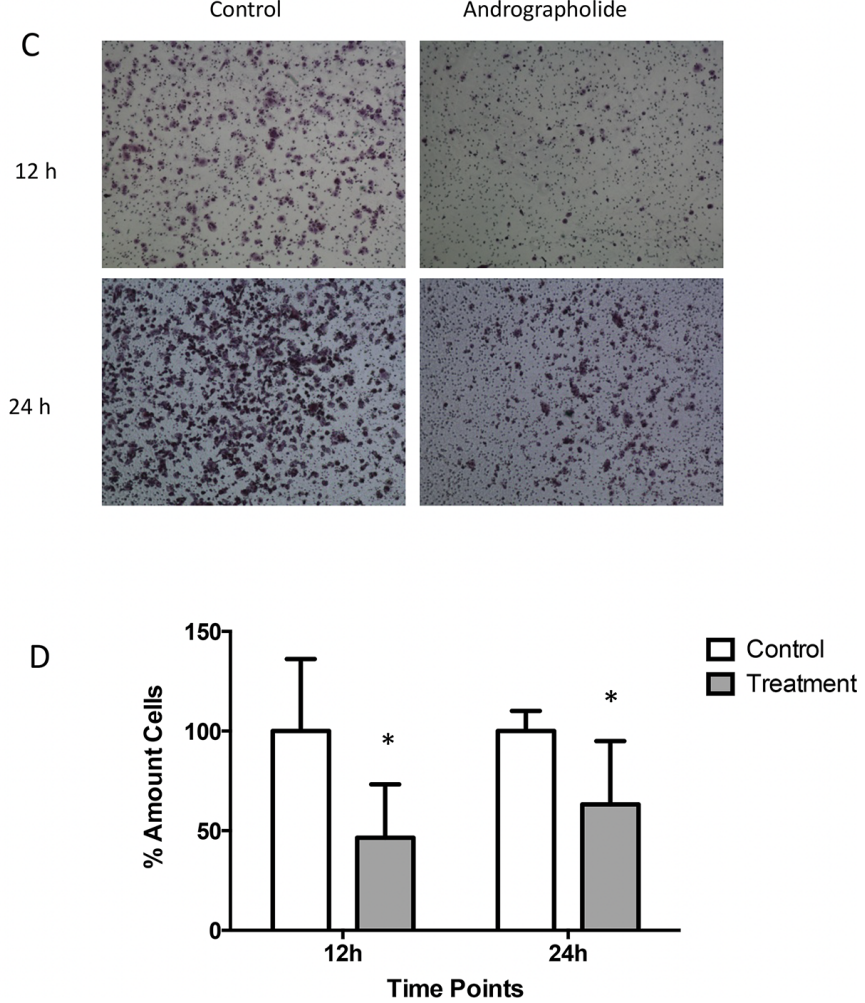

Figure 2: Andrographolide decreased PC3 cell migration and invasion. (A) Confluent monolayer of PC3 cells was wounded by scratching with a pipette tip and were incubated with or without Andrographolide for 0,12 and 24 hours. Photomicrographs were taken of PC3 treated with Andrographolide at 0,12 and 24 hours. (B) Quantification of percentage of migration showed that Andrographolide significantly reduced cell migration at 12 and 24 hours when compared to control. (C) To evaluate Andrographolide effect in invasion, PC3 cells were incubated for 12 hours and 24 hours with or without Andrographolide. Invasion was evaluated using the boyden chamber method. Photomicrographs were taken of PC 3 treated with Andrographolide for 12 hours and 24 hours. (D) Andrographolide significantly reduced cell invasion. Experiments were made in triplicate. Statistical analysis was performed using $t$-test. Mean $+\mathrm{SEM}\left({ }^{*} P<0.05\right)$. 
(BLM), Breast cancer 2, early onset (BRCA2), BRCA1 interacting protein C-terminal helicase 1(BRIP1), Nibrin (NBN), partner and localizer of BRCA2 (PALB2) (Table 1). Andrographolide significantly increased the expression of ATM, BRCA2, BRIP1, CLSPN, and NBN. Also, an increase in BLM and PALB2 genes expression was also observed in tumors treated with Andrographolide. (Figure 6). The primers used for real time PCR confirmation are listed in Table 2.

\section{Andrographolide increases histone $\mathrm{H2AX}$ phosphorylation in prostate cancer cells}

Immunofluorescence studies were performed in 22RV1, PC3 and normal (RWPE1) cells to determine the effect of Andrographolide in the levels of phosphorylated histone $\mathrm{H} 2 \mathrm{AX}(\gamma \mathrm{H} 2 \mathrm{AX})$, a marker of DNA doublestrand breaks [24]. We found that, 24 hours after of Andrographolide treatment $(25 \mu \mathrm{M})$, there was a significant 1.6-fold increase in $\gamma \mathrm{H} 2 \mathrm{AX}$ in 22RV1 cell line (Figure 7A, 7B). These results indicate that Andrographolide induces DNA double-strand breaks. For PC3 cells we found that there was a 0.6 -fold increase in $\gamma \mathrm{H} 2 \mathrm{AX}$ when treated with Andrographolide for 24 hours (Figure 7C, 7D). For normal prostate cells, we found that Andrographolide has no effect in the levels of $\gamma \mathrm{H} 2 \mathrm{AX}$ (Figure 7E, 7F).

\section{Andrographolide induces DNA Damage in PC3 cells}

To further evaluate the presence of DNA damage in Andrographolide treated cells, we used a flow cytometry
A

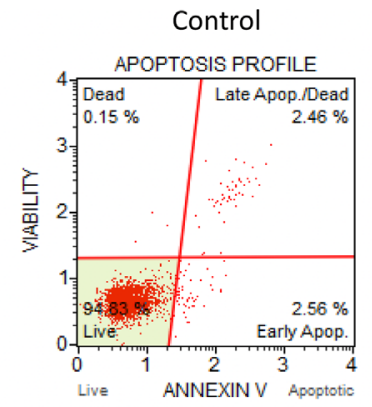

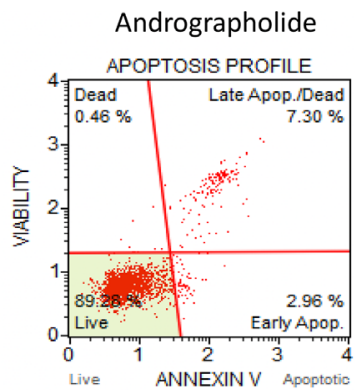

PC3

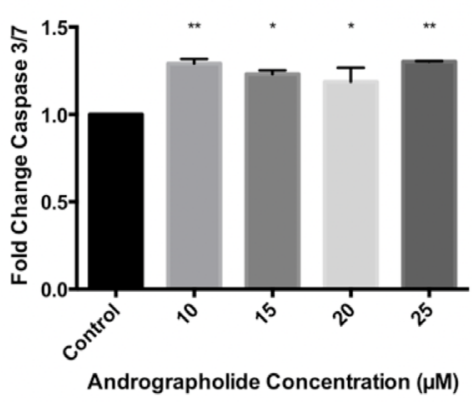

Control

C

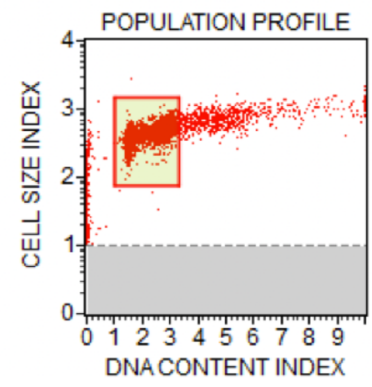

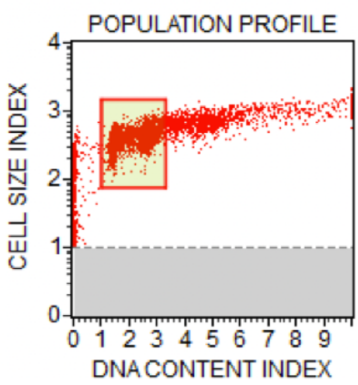

Andrographolide
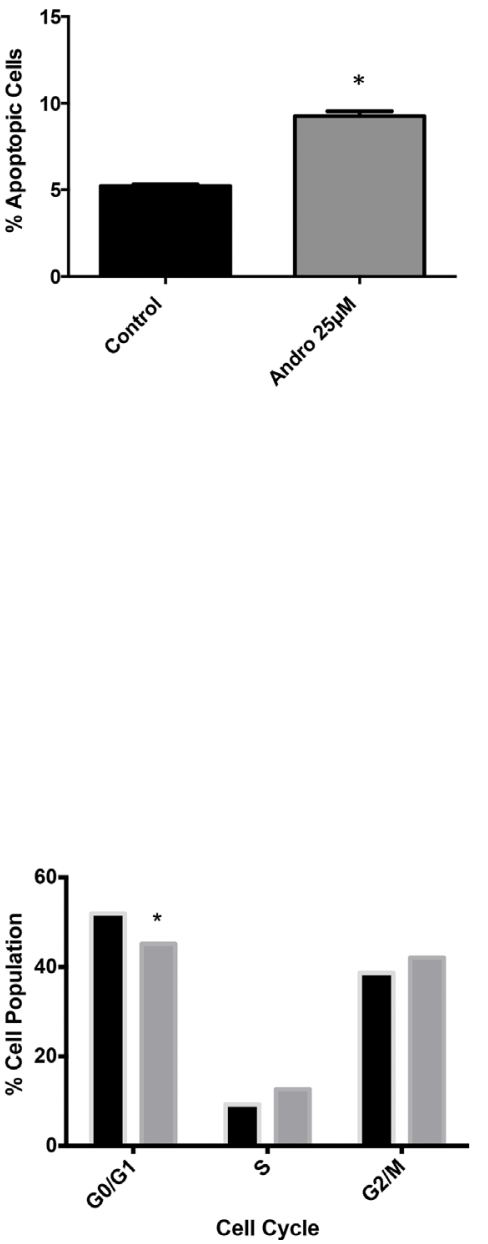

- Control

Andro $25 \mu \mathrm{M}$

Figure 3: Andrographolide increased apoptosis and decreased cell cycle in PC3 cells. PC3 cells were incubated for 24 hours and 48 hours with or without Andrographolide. (A) PC3 cells apoptosis was evaluated using flow cytometry (Annexin-V) after 48 hours and measuring Caspase 3/7 activity after 24 hours. Andrographolide significantly increased Annexin-V in PC 3 cells when compared to control. (B) Andrographolide significantly increased relative activity of Caspase 3/7 in PC3 cell line when compared to control. (C) Cell cycle was evaluated using flow cytometry in PC3 cells. Andrographolide $(25 \mu \mathrm{M})$ significantly reduced cell population at G1/G0 phase and increased cell population at G2/M stage after 48 hours of treatment. Experiments were made in triplicate. Statistical analysis was performed using $t$-test. Mean $+\operatorname{SEM}\left({ }^{*} P<0.05\right)$. 
method that detects phosphorylated ATM and $\gamma \mathrm{H} 2 \mathrm{AX}$. DNA damage is expressed as the percent of cells that simultaneously display both markers. PC3 cells treated with $25 \mu \mathrm{M}$ Andrographolide for 24 hours show a significant increase in DNA damage as compared to control cells (Figure 8). For this assay, 22RV1 cells were no evaluated because they grow in clusters and cannot be processed by the flow cytometer.

\section{DISCUSSION}

Andrographolide, whose major component is diterpene lactone, has been shown to possess antitumor properties. However, its mechanism of action is not fully understood. It has been observed that Andrographolide inhibits cancer cell proliferation, induces cell-cycle arrest, and promotes apoptosis [18, 25, 26]. Previous studies showed the potential of Andrographolide as a chemopreventive agent by suppressing growth of cancer cells by inhibiting NF- $\kappa \mathrm{B}, \mathrm{PI} 3 \mathrm{~K} / \mathrm{AKT}$ and other kinase pathways and by inducing apoptosis $[8,27]$. In prostate cancer, Andrographolide has been known to inhibit cell viability and cell migration by modulating CXCL11, CXCR3, CXCR7, and IL-16 expression [28, 29]. Nevertheless, the role of Andrographolide in PCa progression has not been elucidated.

In this work, we evaluated the effects of Andrographolide in $\mathrm{PCa}$ using in vitro and in vivo models. We focused on cell migration, invasion, tumor growth, proliferation, angiogenesis, changes in gene expression and DNA repair. We assessed the efficacy of Andrographolide in vitro using PC3, 22RV1 LNCaP PCa cell lines and RWPE1 prostate cells. Andrographolide exhibits anti-proliferative activity on these cells in a dose-dependent manner. LNCaP are less sensitive to this compound, as compared to PC3 and 22RV1 cells. Thus, Andrographolide has potential to target PCa cells that are aggressive in nature. In contrast, the same doses
A

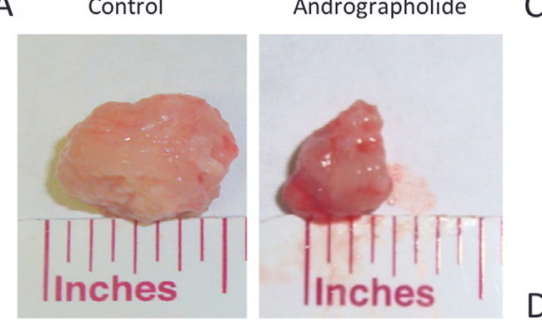

B

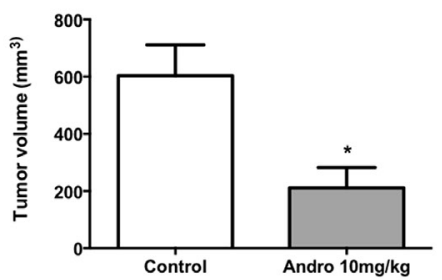

C
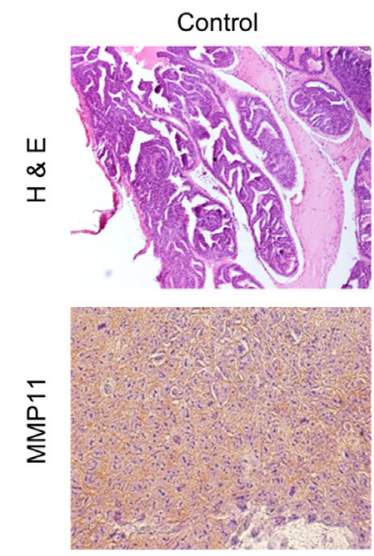

E
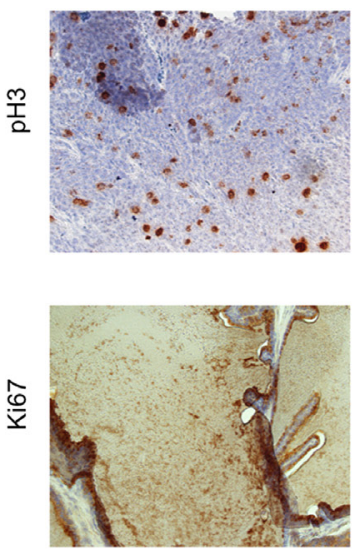

Andrographolide
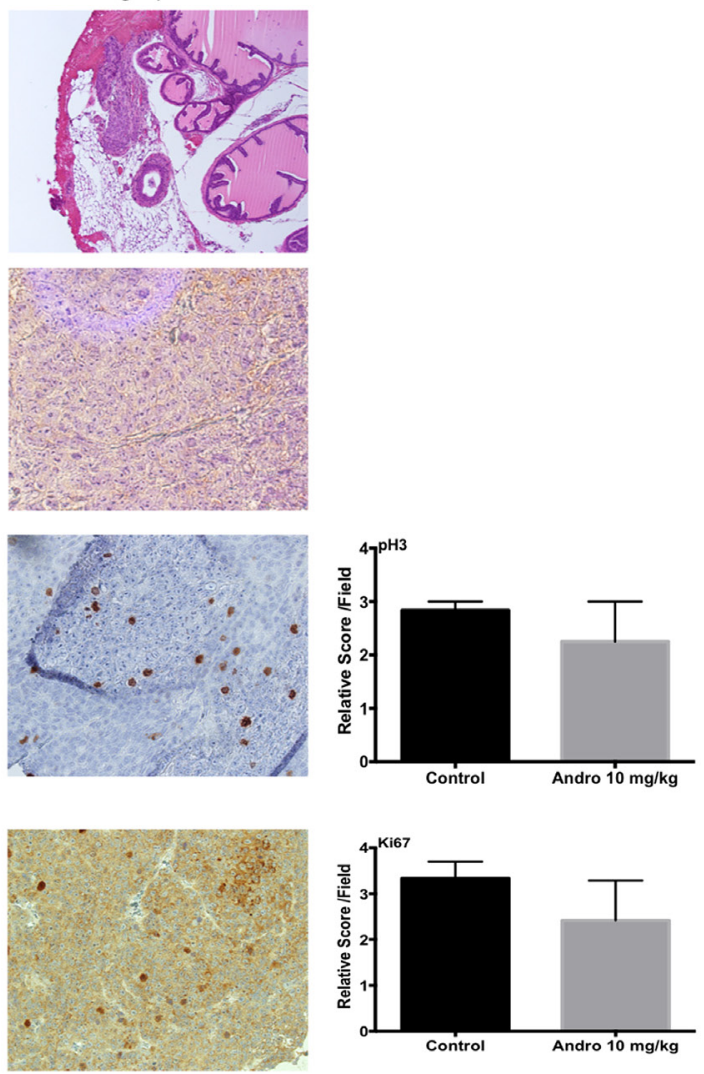

Figure 4: Andrographolide decreased tumor growth, MMP11 expression and proliferation. Tumor growth was evaluated using an orthotopic model. Anterior prostate lobes were injected with 22RV1 cells. Tumors were allowed to develop for 4 weeks and Andrographolide was administered three times per week with intraperitoneal injections. The tumor volume was determined with caliper measurements. (A) Representative images of tumors show differences in size. (B) Tumor volume quantification. $\mathrm{N}_{\text {control }}=6, \mathrm{~N}_{\text {Andrographolide }}=6$. Mean + SEM ( $\left.{ }^{*} P<0.05\right)$. (C) Representative images of vehicle and Andrographolide $10 \mathrm{mg} / \mathrm{kg}$ tumors for hematoxylin and eosin (H \& E) (D) We measured the expression of MMP11 on tumors treated with Andrographolide $10 \mathrm{mg} / \mathrm{kg}$ and control. (E) The expression of pH3 and Ki-67 was evaluated in 22RV1 tumor tissue. Vehicle at the left; Andrographolide $10 \mathrm{mg} / \mathrm{kg}$ at the right. Andrographolide $10 \mathrm{mg} / \mathrm{kg}$ reduced cell proliferation in vivo. Statistical analysis was performed using $t$-test. Mean $+\operatorname{SEM}\left({ }^{*} P<0.05\right)$. 
did not inhibit the proliferation of RWPE1, a cell line derived from normal human prostate cells. We observed that cell population remained constant at higher doses. This strongly suggests that Andrographolide is not toxic for normal prostate cells. The resistance of noncancerous cells to Andrographolide will require additional study but this characteristic strengthens the rationale the use of Andrographolide as a chemotherapeutic agent. We observed that Andrographolide inhibited cancer cell motility and invasion in prostate cancer cells. Further, results show that Andrographolide induces cellular apoptosis via changes in caspase 3/7 activity. Previous studies have shown that the protein TRAIL is capable of initiating apoptosis through the activation of caspases-3 and $-7[30,31]$. Our results show that Andrographolide can restrain proliferation and stimulate apoptosis in aggressive prostate cancer cells specifically in androgen insensitive (AI) cell (PC3) since cancer cells that undergoes androgen receptor (AR) activation can cause proliferation and block apoptosis [32]. Additionally, flow cytometry with Annexin $\mathrm{V}$ staining was conducted to quantify apoptotic cells. An increase of apoptotic cells was observed in PC3-treated cells. This result further validated that Andrographolide could inhibit the growth of prostate cancer cells and subsequently induce apoptosis.

DNA damage is a molecular event which is closely associated with cell cycle arrest and apoptosis. To date, several studies showed that Andrographolide effectively induces cell cycle arrest at G0/G1 stage in most of the cancer cells $[10,33]$. Our findings show that
A
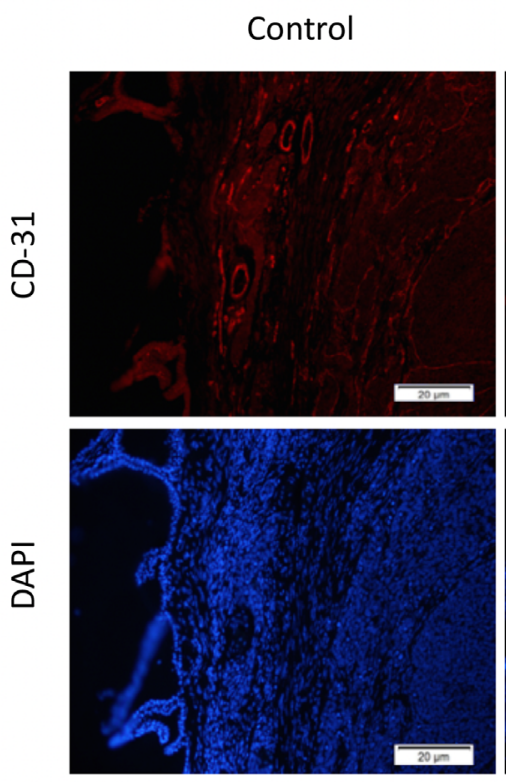

B

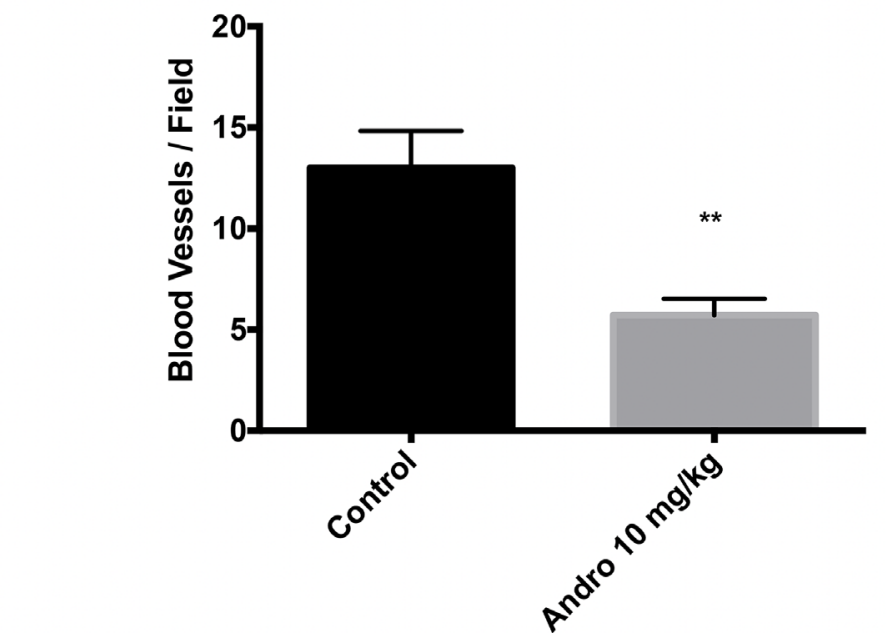

Andrographolide

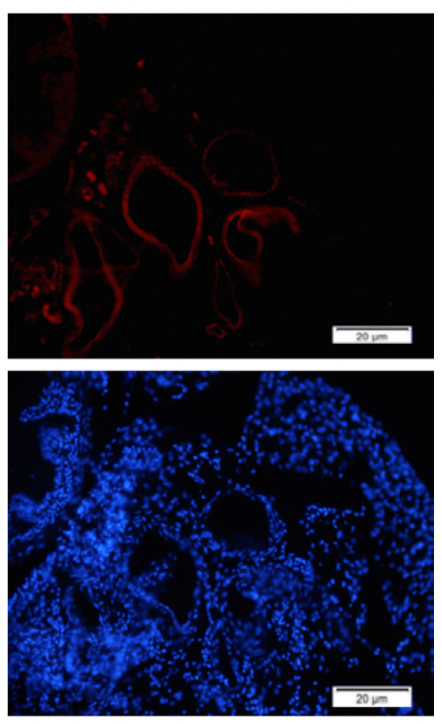

B

Figure 5: Andrographolide decreased CD31 expression. (A) The expression of CD31 was evaluated in 22RV1 tumor tissue. Vehicle at the left; Andrographolide $10 \mathrm{mg} / \mathrm{kg}$ at the right. Nuclei are stained in blue and blood vessels are stained in red. (B) Andrographolide significantly reduced CD31 expression. Experiments were made in triplicate. Statistical analysis was performed using $t$-test. Mean + SEM $\left({ }^{*} P<0.05\right)$. 
Table 1: Microarray analysis: Genes associated with cell cycle and DNA repair altered by Andrographolide in vivo

\begin{tabular}{|c|c|c|c|c|}
\hline Gene symbol & Description & Fold change & $P$ value & qPCR-P value \\
\hline ATM & $\begin{array}{c}\text { ATM serine/threonine } \\
\text { kinase }\end{array}$ & 2.14 & $3.07 \mathrm{E}-02$ & $2.15 \mathrm{E}-02$ \\
\hline$B L M$ & $\begin{array}{l}\text { Bloom syndrome, } \\
\text { RecQ helicase-like }\end{array}$ & 2.49 & $3.15 \mathrm{E}-02$ & $3.21 \mathrm{E}-01$ \\
\hline$B R C A 2$ & $\begin{array}{c}\text { Breast cancer 2, early } \\
\text { onset }\end{array}$ & 2.23 & $3.90 \mathrm{E}-02$ & $1.50 \mathrm{E}-03$ \\
\hline BRIP1 & $\begin{array}{c}\text { BRCA1 interacting } \\
\text { protein C-terminal } \\
\text { helicase } 1\end{array}$ & 2.08 & 4.35E-02 & $2.30 \mathrm{E}-02$ \\
\hline CLSPN & Claspin & 2.06 & 2.91E-02 & $4.28 \mathrm{E}-02$ \\
\hline$N B N$ & Nibrin & 2.18 & $2.94 \mathrm{E}-02$ & $2.10 \mathrm{E}-02$ \\
\hline PALB2 & $\begin{array}{c}\text { partner and localizer } \\
\text { of BRCA2 }\end{array}$ & 2.99 & $2.47 \mathrm{E}-03$ & $2.04 \mathrm{E}-01$ \\
\hline
\end{tabular}

Andrographolide decreased cell population at G0/G1 stage but increased cell population at $\mathrm{G} 2 / \mathrm{M}$ phase. This arrest may be due to different cyclin-dependent kinase (CDKs) activities being regulated with the association of their cyclin partners, kinases, phosphatases and specific inhibitors [34]. The deregulation of cyclins (D \& E) and cdks $(2,4 \& 6)$ can results in abnormal growth of cells since they play important roles in the progression of cells through the $\mathrm{G}_{0} / \mathrm{G}_{1}$ phase of the cell cycle [35]. Therefore, further research is needed to examine the detail mechanism of cell cycle arrest in Andrographolide-treated PC3 prostate cancer cells.
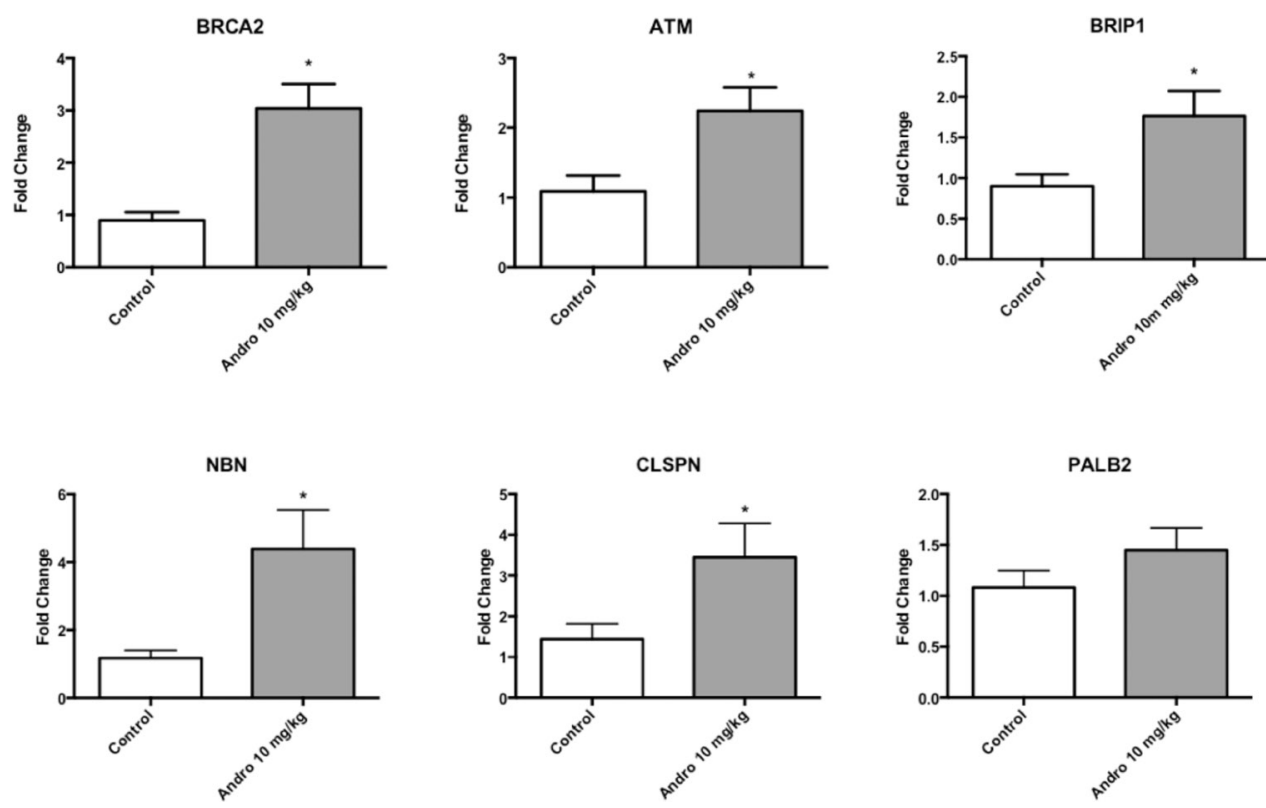

Figure 6: Andrographolide $10 \mathrm{mg} / \mathrm{kg}$ altered genes associated with DNA repair. Real time PCR results for: ATM serine/ threonine kinase (ATM), Bloom syndrome, RecQ helicase like (BLM), Breast cancer 2, early onset (BRCA2), BRCA1 interacting protein C-terminal helicase 1(BRIP1), Nibrin (NBN), partner and localizer of BRCA2 (PALB2). Experiments were made in triplicate. Statistical analysis was performed using $t$-test. Mean $+\operatorname{SEM}\left({ }^{*} P<0.05\right)$. 
Table 2: Primer sequences for qRTPCR analysis of genes affected by Andrographolide in vivo

\begin{tabular}{lcc}
\hline Primer & \multicolumn{1}{c}{ Sense } & Antisense \\
\hline BRCA2 & 5'-GAAGCCCTTTGAGAGTGGAA-3' & 5'-CTCCATCTGGGCTCCATTTAG-3' \\
ATM & 5'-TGCACTGAAAGAGGATCGTAAA-3' & 5'-CAGAGGGAACAAAGTCGGAATA-3' \\
NBN & 5'-CCACACATCATTGGAGGATCA-3' & 5'-GTACCTCCATTTCCTGCCTTAG-3' \\
BRIP1 & 5'-CAGCTGGAGGCTAATCATATC-3' & 5'-CTGGAAGGTAGCACAGAGATTC-3' \\
CLSPN & 5'-GGAGGAGGAATTTGGAGACTTT-3' & 5'-TCTTCCAGTGCCAGATCATTAC-3' \\
BLM & 5'-CAGGATGGCTGTCAGGTTATC-3' & 5'-GGTAGTAACCCTCCACAGATTTAG-3' \\
PALB2 & 5'-CTGGAAGGTGACGTGAAAGA-3' & 5'-CAGTACACTGACCGAGAAGTAAG-3' \\
\hline
\end{tabular}

and basement membrane degradation, we measured its expression in tumors treated with Andrographolide $[41,42]$. MMPs promote the formation of new blood vessels, and are involved in numerous processes associated with tumor cell growth, differentiation, invasion, diffusion and metastasis [41, 42]. Our results show that Andrographolide decreases the expression of MMP11 in tumor tissue. Furthermore, our results show that Andrographolide decreases the number of blood vessels, confirming the observed inhibition in tumor growth. The contribution of MMPs to angiogenesis is not only by the degradation of basement membrane that cause endothelial cells to detach and migrate into new tissue, but also by releasing proangiogenic factors, bound to ECM, such as bFGF, VEGF, and TGF $\beta$ [43].

Additionally, we measured if Andrographolide inhibited profileration in vivo. We observed that Andrographolide $10 \mathrm{mg} / \mathrm{kg}$ decreased $\mathrm{pH} 3$ and $\mathrm{Ki}-67$ expression in tumor tissue. These findings are important since proliferation is one of the cancer hallmarks. One
A

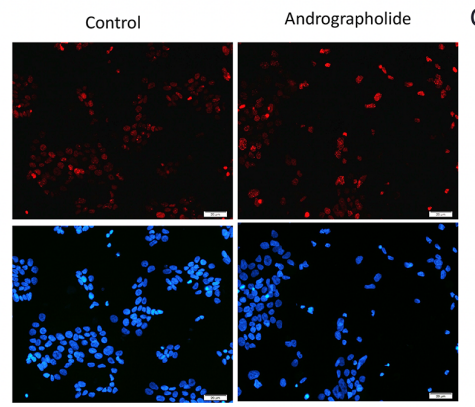

B

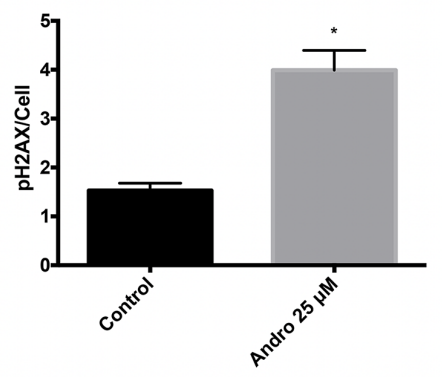

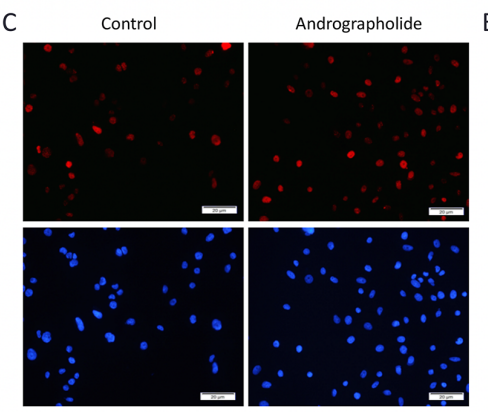
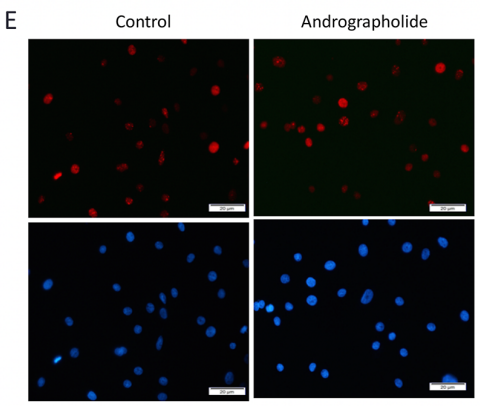

D
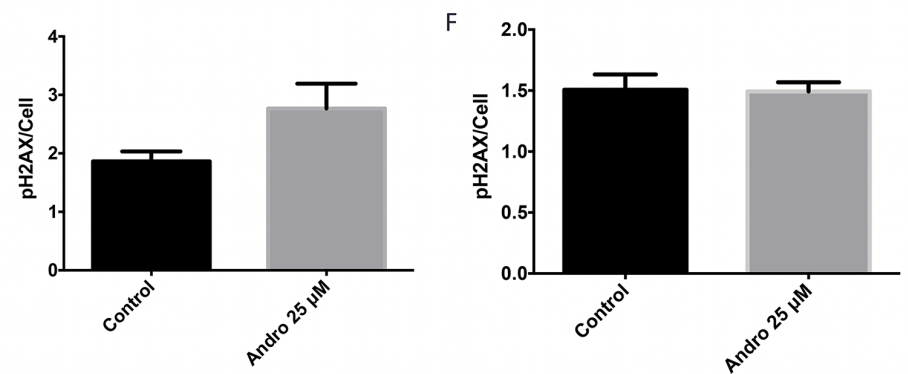

Figure 7: Andrographolide increased expression of phospho-H2AX histone in prostate cancer cells. To evaluate the effect of Andrographolide in phospho-H2AX, a double strand DNA break marker, 22RV1, PC3 and normal prostate cells were treated with $25 \mu \mathrm{M}$ of Andrographolide and incubated for 24 hours. (A) Representatives images of phospho-H2AX staining for $22 \mathrm{RV} 1$ cells treated with Andrographolide. Vehicle (left panel); Andrographolide $25 \mu \mathrm{M}$ (right panel). Nuclei are stained with DAPI (blue) and phospho$\mathrm{H} 2 \mathrm{AX}$ is stained in red. (B) Statistical analysis shows that phospho-H2AX was significantly increased in 22RV1 cells when treated with Andrographolide. (C) Representatives images of phospho-H2AX staining for PC3 cells treated with Andrographolide. Vehicle (left panel); Andrographolide $25 \mu \mathrm{M}$ (right panel). Nuclei are stained with DAPI (blue) and phospho-H2AX is stained in red. (D) Statistical analysis shows that phospho-H2AX was increased in PC3 cells when treated with Andrographolide. (E) Representatives images of phospho-H2AX staining for normal prostate (RWPE1) cells treated with Andrographolide. Vehicle (left panel); Andrographolide $25 \mu \mathrm{M}$ (right panel). Nuclei are stained with DAPI (blue) and phospho-H2AX is stained in red. (F) Statistical analysis shows that phospho-H2AX levels did not change in RWPE1 cells when treated with Andrographolide. Experiments were made in triplicate. Statistical analysis was performed using $t$-test. Mean + SEM $\left({ }^{*} P<0.05\right)$. 
of the main mutation in prostate cancer includes PTEN gene. It is known that loss of function in PTEN amplify $\mathrm{PI} 3 \mathrm{~K}$ signaling and promote tumorigenesis in a variety of experimental models of cancer. Although we found that Andrographolide arrests cell cycle at G2/M phase, more studies will need to be conducted to understand the specific mechanism whereby Andrographolide is decreasing these two proliferation markers.

Our microarray and real time PCR experiments indicate that Andrographolide induces the expression of genes associated with double strand break DNA repair in tumors. The expression of ATM serine/threonine kinase (ATM), Bloom syndrome, RecQ helicase like (BLM), Breast cancer 2, early onset (BRCA2), BRCA1 interacting protein C-terminal helicase 1(BRIP1), Nibrin (NBN), partner and localizer of BRCA2 (PALB2) was increased in tumors treated with Andrographolide $10 \mathrm{mg} / \mathrm{kg}$.

It has been suggested that BRIP1 may have an antioncogenic role, and its downregulation has been observed in multiple types of cancer [44]. Given that BRIP1 has an essential function in the regulation of normal cell cycle progression and DNA repair, the BRIP1 gene represents a good candidate for prediction of genetic susceptibility to cancer [45-48]. Our results show that Andrographolide increased the expression of BRIP1. BRCA2 plays a limited role in DNA recombination and repair processes, but seems to be a key player in the regulation of the RAD51 recombinase activity, a protein involved in repairing double stranded DNA breaks [49-51]. We showed that Andrographolide increased the expression of BRCA2 gene. Furthermore, our results show that Andrographolide increased the expression of ataxia-telangiectasia mutated (ATM) in prostate tumors. ATM is a serine/threonine protein kinase belonging to the PI3K family and it functions as a key mediator of DNA damage response and induces cell cycle arrest [52].

NBN function in combination with RAD50 and MRE11 proteins to form the MRN complex, responsible for the detection of DSBs and the subsequent activation of repair mechanisms [53]. Consequently, NBN is expected to act as a tumor suppressor gene by recruiting ATM [53]. Interestingly, this gene was demonstrated to be increased
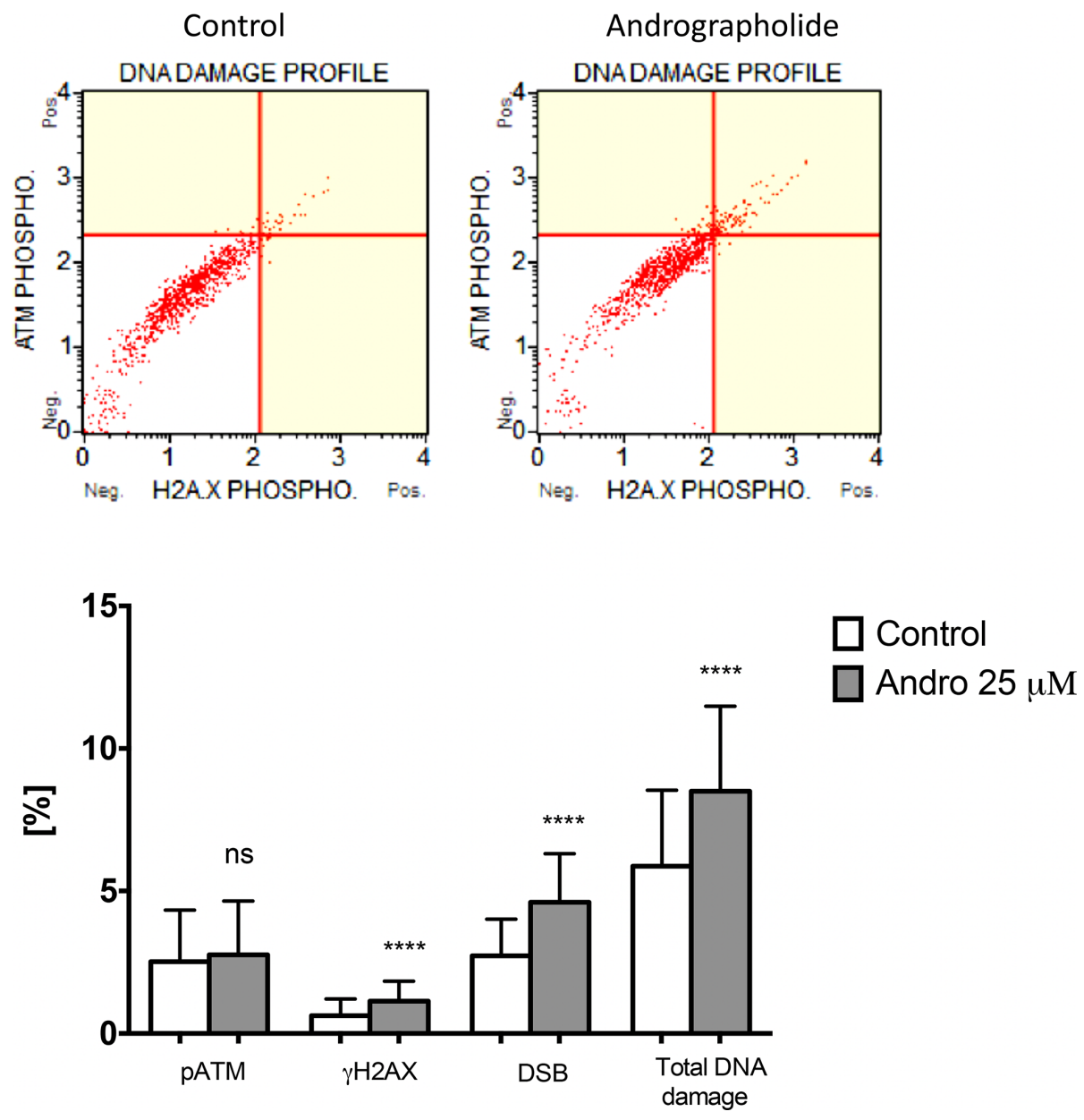

Figure 8: Andrographolide increases DNA damage in PC3 cells. Cells were incubated with Andrographolide $25 \mu \mathrm{M}$ or vehicle (Control) for 24 hours. DNA damage was determined with a flow cytometry approach that detects cells that simultaneously express phosphorylated ATM and $\gamma \mathrm{H} 2 \mathrm{AX}$. DNA damage is presented relative to Control cells, which is set at 1 . Experiments were made in triplicate. Statistical analysis was performed using $t$-test. Mean $\pm \operatorname{SEM}\left({ }^{*} P<0.001\right)$. 
by Andrographolide in tumors. On the other hand, it is well known that BLM mutations lead to Bloom Syndrome, a disease characterized by growth retardation and predisposition to cancer $[54,55]$. Therefore, an increased expression of this gene will be essential to reduced cancer predisposition. We showed that Andrographolide increased the expression of BLM gene. PALB2 was found as a tumor suppressor gene [56]. Accordingly, we found that Andrographolide increased the expression of this tumor suppressor.

We determined the phosphorylation status of the $\mathrm{H} 2 \mathrm{AX}$ histone $(\gamma \mathrm{H} 2 \mathrm{AX})$ to confirmed an increase in double strand breaks since $\gamma \mathrm{H} 2 \mathrm{AX}$ functions as an early indicator of DNA double-strand breaks (DSB) and of the resulting response (DNA damage response [DDR]) [24, 57]. Histone $\mathrm{H} 2 \mathrm{AX}$ is a substrate of several phosphoinositide 3-kinaserelated protein kinases (PIKKs), such as ATM, which is considered a major physiological mediator of $\mathrm{H} 2 \mathrm{AX}$ phosphorylation in response to DSB formation [58]. We found that Andrographolide significantly increased $\gamma \mathrm{H} 2 \mathrm{AX}$ in 22RV1 cells. This finding is in accordance with the increased expression of double-strand break DNA repair genes after Andrographolide that we report. Furthermore, using a method that simultaneously detects phosphorylated ATM and $\gamma \mathrm{H} 2 \mathrm{AX}$ we observed that Andrographolide induces DNA damage in PC3 cells. ATM is known to phosphorylate checkpoint kinase 2 (CHK2) which in turn phosphorylates the tumor suppressor p53, disrupting its binding to its negative regulator MDM2. This results in p53 protein stabilization and allows p53 to mediate its downstream effect on cell growth suppression [59, 60]. Consequently, the activation of the above-mentioned cell cycle checkpoints can result in suppression of cell growth and activation of apoptosis. It has been observed that the functional status of p53 is important in the progression of prostate cancer and its response to treatment. Androgendependent cells, 22RV1 are known to have the presence of wild type p53, while androgen-independent, PC3 cells are known to be p53 null [61]. This can explain our findings where Andrographolide decreased PC3 cell proliferation after 48 hours but after 24 hours for 22RV1 line.

In summary, we evaluated several hallmarks of cancer like proliferation, cell motility, tumor growth, angiogenesis, and changes at the genetic level. Importantly, we observed that Andrographolide increased genes associated with double strand DNA repair. This increase may explain the mechanism whereby Andrographolide induces a DNA damage response involving cell growth suppression, cell cycle arrest and apoptosis. Specifically, DNA double strand break-dependent ATM activation may result in p53 activation, which result in apoptosis and arrest of cell cycle. Taken together, we have shown that Andrographolide is an effective anti-cancer compound for prostate cancer by regulating genes associated to double-strand breaks such as ATM, NBN, BRCA2 BLM, PALB2 and BLM. This innovative finding is essential to understand the mechanism of action of Andrographolide in prostate cancer. Further studies are needed to delineate the mechanisms by which Andrographolide suppresses prostate cancer progression in vivo.

\section{MATERIALS AND METHODS}

\section{Cell culture}

Human androgen-independent prostate cancer cells PC3, human androgen-dependent prostate cancer cells 22RV1 and LNCaP, and human normal prostate cells RWPE-1 were purchased from American Type Culture Collection (ATCC), (Manassas, VA, USA). The PC3, 22RV1 and LNCaP cell lines were maintained in RPMI-1640 medium with L-glutamine (Hyclone, MA, USA) supplemented with $10 \%$ fetal bovine serum (FBS), $100 \mathrm{U} / \mathrm{mL}$ penicillin and $100 \mu \mathrm{g} / \mathrm{mL}$ streptomycin (Gibco, Carlsbad, CA, USA). RWPE1 cells were maintained in Keratinocyte-SFM supplemented with L-glutamine, $0.05 \mathrm{mg} / \mathrm{mL}$ of Bovine Pituitary Extract (BPE) and $5 \mathrm{ng} / \mathrm{mL}$ of Epidermal Growth Factor (EGF) (Gibco, NY, USA). Cells were maintained in a $5 \% \mathrm{CO}_{2}$ humidified atmosphere at $37^{\circ} \mathrm{C}$.

\section{Andrographolide solution}

Andrographolide was obtained from Sigma-Aldrich (Saint Louis, MO, USA), dissolved in dimethyl sulfoxide (DMSO) at a concentration of $100 \mathrm{mM}$, and then diluted with complete growth medium to the final desired concentration. Samples treated with DMSO alone were used as vehicle.

\section{Cell viability}

Cell viability and proliferation were assessed using CellTiter $96^{\circledR} \mathrm{AQ}_{\text {ueous }}$ One Solution Cell Proliferation Assay (MTS) (Promega, Madison, WI, USA) and was used according to the manufacturer's instructions. A total of 10,000 cells per well of PC3, 22RV1, LNCaP and RWPE1 were grown in a 96-multiwell plate. After 24 hours of incubation cells were treated with DMSO (control) and Andrographolide at concentrations of 10, 15, 20 and $25 \mu \mathrm{M}$ in fresh complete medium. MTS reagent was added at 24 and 48 hours of treatment and incubated for 2 hours. Absorbance was measured at $490 \mathrm{~nm}$ using a xMark Microplate Absorbance Spectrophotometer (BIORAD, USA). $\mathrm{GI}_{50}$ was determined by calculating percent of inhibition as $[(\mathrm{C}-\mathrm{T}) / \mathrm{C}] \times 100(\mathrm{C}=$ control; $\mathrm{T}=$ treatment) and using the slope equation $\mathrm{y}=\mathrm{mx}+\mathrm{b}$ where $y=50$. Experiment was carried out in triplicates and data was analyzed using GraphPad Prism ANOVA followed by Dunnett's comparison at $95 \%$ confidence interval.

\section{Cell migration assay}

Cell migration was assessed using the scratch (wound healing) method. PC3 cells were grown in 6-well tissue 
culture plates until 95\% confluency. A scratch was made through the confluent monolayer using a sterile plastic 200 $\mu \mathrm{L}$ pipette tip. Cells were gently washed with PBS and incubated at $37^{\circ} \mathrm{C}$ in RPMI-1640 supplemented with $10 \%$ fetal bovine serum in the presence of vehicle (DMSO) or Andrographolide $(25 \mu \mathrm{M})$. Cells were photographed using a Nikon Eclipse TS100 microscope (Nikon, Tokyo, Japan) at 12 and 24 hours of treatment at a $4 \times$ magnification. A total of 10 distance measurements within each wound were obtained and analyzed using Image Pro Plus Software. The differences in wound closure were normalized to 0 hours according to the treatment and compared to the control using Student's T-test at a 95\% confidence interval. All experiments were performed in triplicate.

\section{Cell invasion assay}

PC3 and 22RV1 cells $\left(4 \times 10^{4} /\right.$ well $)$ were seeded in the upper chamber of a transwell system (Corning Incorporated, NY, USA) in serum-free medium, with or without Andrographolide $(25 \mu \mathrm{M})$ and invasion assay was carried out according to the manufacturer's instructions. Serum-containing medium was added to the lower chamber to act as a chemotactic attractant. At 12 and 24 hours of incubation, the upper chamber was removed and unmigrated cells were removed with PBS. Cell that migrated across the membrane were fixed with $10 \%$ formalin, stained with hematoxylin overnight, washed with deionized water, and these membranes were mounted on slides. Photographs at a $4 \times$ magnification were captured with a Nikon Eclipse TS100 microscope (Nikon, Tokyo, Japan). The number of invasive cells was counted using Image Pro Plus Software. Results were analyzed using the Student's $T$-test at a 95\% confidence interval. All experiments were performed in triplicate.

\section{Flow cytometry}

Cell cycle, apoptosis and DNA damage assays were performed using flow cytometry with the Muse ${ }^{\circledR}$ Cell Analyzer instrument (EMD Millipore Merck KGaA, Darmstadt, Germany). Cell cycle was assayed by incubating PC3 cells $\left(2.5 \times 10^{6}\right.$ cells $\left./ \mathrm{mL}\right)$ with DMSO (control) or Andrographolide $(25 \mu \mathrm{M})$ for 24 and 48 hours and cells (detached and attached) were collected and fixed with ethanol 70\%. Muse ${ }^{\circledR}$ Cell Cycle Assay Kit was used following manufacturer's instructions. Annexin-V was used to determined apoptosis in PC3 cell line. Cells $\left(1 \times 10^{7}\right.$ cells $\left./ \mathrm{mL}\right)$ were incubated with DMSO (control) or Andrographolide for 24 and 48 hours and all cells (detached and attached) were stained using Muse ${ }^{\circledR}$ Annexin-V Kit following manufacturer's instructions. DNA damage was assayed by incubating PC3 cells with DMSO or Andrographolide $25 \mu \mathrm{M}$ for 24 hours and cells were collected, fixed and permeabilized. Cells were evaluated using Muse ${ }^{\mathrm{TM}}$
Multi-Color DNA Damage Kit following manufacturer's instructions. The experiments were done in triplicates and data were analyzed using GraphPad Prism Student $t$-test at $95 \%$ confidence interval.

\section{Apoptosis assay}

Caspase $3 / 7$ activity was measured to evaluate apoptosis in PC3 and 22RV1 cell lines. A total of 10,000 cells per well were seeded in a 96-white walled multiwell plate. After 24 hours of incubation, cells were treated with DMSO (control) and Andrographolide (10, 15, 20 and $25 \mu \mathrm{M})$ in fresh complete medium. Following treatment, Caspase-Glo 3/7 reagent was added and incubated at room temperature for $60 \mathrm{~min}$. Caspase-3/7 activities were determined by quantifying luminescence. Experiments were performed in triplicates and data were analyzed using GraphPad Prism ANOVA followed by Dunnett's comparison at $95 \%$ confidence interval.

\section{Orthotopic mouse model}

All animal studies were carried out in accordance to the Institutional Animal Care and Use Committee regulations. Seven to eight weeks male ICR-SCID mice (Taconic, Germantown, NY, USA) were housed and maintained in a pathogen-free animal facility. An orthotopic xenograft model in which 22RV1 $(250,000$ cells) were injected in the anterior prostate lobes was used. Cells suspended in PBS were placed in $30 \mu \mathrm{L}$ of collagen I (Becton Dickinson, Franklin Lakes, NJ, USA), allowed to slightly solidify and injected in the anterior prostate lobes. Mice were intraperitoneally injected three times per week with Andrographolide (10 mg/kg) or vehicle (saline). After 4 weeks of treatment, tumors were collected, measured, and fixed in $10 \%$ buffered formalin or snapped frozen.

\section{Hematoxylin-eosin staining}

Paraffin-embedded tumor tissue sections (5 $\mu \mathrm{m})$ were deparaffinized in xylene and hydrated using serial descending concentrations of alcohol. Tissue was stained with hematoxylin followed by stain differentiation with $1 \% \mathrm{v} / \mathrm{v}$ acid alcohol (80\% ethanol, 19\% deionized water, $1 \% \mathrm{HCl}), 0.3 \% \mathrm{v} / \mathrm{v}$ ammonia water $\left(0.3 \% \mathrm{NH}_{4} \mathrm{OH}\right.$ in deionized $\mathrm{H}_{2} \mathrm{O}$ ) and washing with $70 \%$ ethanol. After eosin staining $(0.05 \%$ Eosin $\mathrm{Y}$ in $70 \%$ Ethanol- $0.005 \%$ acetic acid), sections were dehydrated with increasing serial dilutions of ethanol and xylene. Slides were mounted using permount mounting medium. $n=5$ representative tumors for control group and $n=4$ representative tumors for Andrographolide $10 \mathrm{mg} / \mathrm{kg}$ group. 


\section{Immunohistochemistry and immunofluorescence in vivo}

Paraffin-embedded tumor tissue sections were dewaxed in xylene and rehydrated using a descending concentration of alcohol. Antigen retrieval was performed using a citrate-based Antigen Unmasking Solution (Vector Laboratories Burlingame, Ca, USA). Endogenous peroxidase was quenched with $3 \% \mathrm{v} / \mathrm{v}_{2} \mathrm{O}_{2}$. Sections were blocked (10\% FBS) for 1 hour followed by an overnight incubation with a primary antibody. The primary antibodies used were CD-31 (1:50), MMP11 (1:500), pH (1:1000) (Abcam, Cambridge; MA, USA) and Ki-67 (1:50) (Vector Laboratories; Burlingame, CA, USA). For immunofluorescence, the secondary antibody used was Alexa-Fluor 594 (anti-rabbit) 1:2000 (Molecular Probes, Life Technologies, Carlsbad, CA, USA) and nuclei were stained with DAPI 1:5000 (Santa Cruz Biotechnology, Santa Cruz, CA, USA). All immunohistochemical sections were detected using Dako Envision system-HRP (DAB) (anti-rabbit) (Dako; Glostrup, Denmark) according to the manufacturer's instructions. Digital photographs were obtained using an Olympus IX71 Inverted microscope (Olympus America, Melville, NY).

\section{Microarray analysis}

Affymetrix gene chip based transcript profiling was carried out at the RCMI Center for Genomics in Health Disparities and Rare Diseases (University of Puerto Rico, Medical Sciences Campus). RNA was isolated from tumor tissue using RNeasy Mini Kit (Qiagen Inc., Valencia; CA, USA). Total RNA (100 ng) was converted to cDNA and amplified using $\mathrm{T} 7$ oligo $\mathrm{dT}$ and the GeneChip ${ }^{\circledR}$ WT cDNA Synthesis Kit, the GeneChip ${ }^{\circledR}$ WT cDNA Amplification Kit, and the GeneChip ${ }^{\circledR}$ Sample Cleanup Module exactly as described in the GeneChip ${ }^{\circledR}$ Whole Transcript (WT) Sense Target Labeling Assay Manual Addendum. Quality control steps were performed to ensure that the RNA was adequate to be used in the first strand cDNA synthesis (10 $\mu \mathrm{g}$ of RNA). A gel-shift analysis of the WT (Whole Transcript) was done to assess the labeling efficiency of the fragmented cDNAs. The image data was normalized using the Expression Console software provided by Affymetrix. Gene expression values and clustering was done using the Transcriptome Analysis Console also provided by Affymetrix. The settings used to identify differences in expression were: a fold change higher than 2 or lower than -2 and a $p$ value lower than 0.05 . Identification of gene expression patterns was done with Ingenuity Pathway Analysis (IPA) software and parameters used were: a fold change higher than 1.5 or lower than -1.5 and a $p$ value lower than 0.05 . To identify the affected functions and networks we used the "diseases and functions" sections of the IPA software. Data was documented according to the MIAME guidelines [62].

\section{Real time PCR validation}

To validate microarray results, quantitative Real time PCR (qRT-PCR) was performed under standard conditions using the Step One Plus Real-time PCR System (Applied Biosystems, Carlsbad; CA, USA). Primers were designed using the Integrated DNA Technologies (IDT) Primer Quest tool. Primers used were: ATM serine/threonine kinase (ATM), Bloom syndrome, RecQ helicase like (BLM), Breast cancer 2, early onset (BRCA2), BRCA1 interacting protein C-terminal helicase 1(BRIP1), Claspin (CLSPN) Nibrin (NBN), and partner and localizer of BRCA2 (PALB2) (Table 2). A BLAST was run to ensure specificity of the sequences. qRT-PCR was performed in $20 \mu \mathrm{L}$ reactions using SYBR super mix (Bio-Rad, Hercules, CA, USA). The cycle used was, $95^{\circ} \mathrm{C}$ for 15 seconds and $62^{\circ} \mathrm{C}$ for 1 minute or $95^{\circ} \mathrm{C}$ for 15 seconds and $56^{\circ} \mathrm{C}$ for 1 minute. PCR efficiency was examined and the melting curve data was collected for PCR specificity. The housekeeping gene used was GAPDH. Quantification was done using the $\Delta \Delta \mathrm{C}_{\mathrm{t}}$ method. No PCR product was detected in control samples in which the template was omitted. Statistical analysis was done with a Mann-Whitney $U$ test at a $95 \%$ confidence interval. A total of three tumors per group were used. Experiments were performed in triplicates.

\section{Immunofluorescence detection of histone H2AX phosphorylation}

22RV1, PC3 and RWPE1 cells were treated with DMSO (control) or Andrographolide at $25 \mu \mathrm{M}$ for 24 hours. Cells were fixed, permeabilized, blocked with FBS (10\%) and stained with DAPI, to visualize nucleus, and phospho$\mathrm{H} 2 \mathrm{AX}(1: 400)$ to measure the amount of phospho-H2AX formed. The secondary antibody used was Alexa-Fluor 594. Digital photographs were obtained using an Olympus IX71 Inverted microscope (Olympus America, Melville, NY). Image Pro Plus was used to determine a ratio of the formation of phospho-H2AX and total cells. The experiment was done in triplicates and data was analyzed using GraphPad Prism Student $t$-test at 95\% confidence interval.

\section{Detection of DNA damage}

DNA Damage assay was performed by flow cytometry using the MUSE Multicolor DNA Damage Kit, following manufacturer's instructions. PC3 cells were treated with DMSO (control) or Andrographolide $(25 \mu \mathrm{M})$ for 24 hours. The experiment was performed using 18 samples, in triplicates and data was analyzed using GraphPad Prism Student $t$-test at 95\% confidence interval.

\section{Statistical analysis}

Statistical analysis was performed using the GraphPad PRISM software. Results represent the mean 
\pm standard error of the mean (SEM). Differences between groups were analyzed using the Student's $t$-test or oneway ANOVA followed by Dunnett's test. $P<0.05$ was considered statistically significant.

\section{Abbreviations}

PCa: prostate cancer; MMP11: matrix metalloproteinase 11; ATM: ATM serine/threonine kinase; BLM: Bloom syndrome, RecQ helicase like; BRCA2: Breast cancer 2, early onset; BRIP1- BRCA1 interacting protein $\mathrm{C}$ : terminal helicase 1; CLSPN- claspin; NBN: nibrin; PALB2: partner and localizer of BRCA2; DSB: DNA double-strand breaks; $\gamma \mathrm{H} 2 \mathrm{AX}$ : phosphorylated H2AX; DDR: DNA Damage Respone; FBS: fetal bovine serum; BPE: bovine pituitary extract; DMSO: dimethyl sulfoxide; qRT-PCR: Real time PCR; IPA: Ingenuity Pathway Analysis; SEM: Standard error of the mean.

\section{Author contributions}

Conception and design of the study: Ingrid ForestierRoman, Magaly Martinez-Ferrer.

Acquisition of data: Ingrid Forestier-Roman, Andrés López-Rivas, Maria Sanchez, Krizia Rohena, Magaly Martinez-Ferrer.

Analysis and interpretation of data: Ingrid ForestierRoman, Maria Sanchez, Krizia Rohena, Gretchen NievesBurgos, Andrés López-Rivas, Humberto Ortiz- Zuazaga, Carlos Torres-Ramos, Magaly Martinez-Ferrer.

Drafting of the article or revising it for important content: Ingrid Forestier-Roman, Maria Sanchez, Krizia Rohena, Humberto Ortiz- Zuazaga, Carlos Torres-Ramos, Magaly Martinez-Ferrer.

Final approval of the version to be published: Magaly Martinez-Ferrer.

\section{ACKNOWLEDGMENTS}

We acknowledge the contribution of Adrianna Rivera and Gabriela Fenollal.

\section{CONFLICTS OF INTEREST}

The authors declare no conflicts of interest.

\section{FUNDING}

This work was partially supported by NIGMS-RISE grant R25GM061838, MARC grant 5T34GM007821-39, NIH INBRE grant P20 GM103475-17, and Institutional funds from the University of Puerto Rico Comprehensive Cancer Center. HOZ was supported in part by NIH-NCI grant U54CA096297. Special thanks to Dr. Carmen Cadilla and Jessica Renta of the RCMI Center for
Genomics in Health Disparities and Rare Diseases (RCMI, Medical Science Campus, grants 8G12-MD007600 and NIMHD:U54-MD007600) for their aid with the sample processing for microarray analysis.

\section{REFERENCES}

1. Torre LA, Bray F, Siegel RL, Ferlay J, Lortet-Tieulent J, Jemal A. Global cancer statistics, 2012. CA Cancer J Clin. 2015; 65:87-108. https://doi.org/10.3322/caac.21262.

2. Siegel RL, Miller KD, Jemal A. Cancer Statistics, 2017. CA Cancer J Clin. 2017; 67:7-30. https://doi.org/10.3322/ caac. 21387.

3. $\mathrm{PDQ}^{\circledR}$ Integrative, Alternative, and Complementary Therapies Editorial Board. PDQ Prostate Cancer, Nutrition, and Dietary Supplements. Bethesda, MD: National Cancer Institute. 2012. Available at: https:/www.cancer.gov/ about-cancer/treatment/cam/hp/prostate-supplements-pdq.

4. Kallifatidis G, Hoy JJ, Lokeshwar BL. Bioactive natural products for chemoprevention and treatment of castrationresistant prostate cancer. Semin Cancer Biol. 2016; 40-41: 160-69. https://doi.org/10.1016/j.semcancer.2016.06.003.

5. Hussain SS, Kumar AP, Ghosh R. Food-based natural products for cancer management: is the whole greater than the sum of the parts? Semin Cancer Biol. 2016; 40-41:23346. https://doi.org/10.1016/j.semcancer.2016.06.002.

6. Li J, Zhang C, Jiang H, Cheng J. Andrographolide inhibits hypoxia-inducible factor-1 through phosphatidylinositol 3-kinase/AKT pathway and suppresses breast cancer growth. Onco Targets Ther. 2015; 8:427-35. https://doi.org/10.2147/ OTT.S76116.

7. Hsieh YL, Shibu MA, Lii CK, Viswanadha VP, Lin YL, Lai CH, Chen YF, Lin KH, Kuo WW, Huang CY. Andrographis paniculata extract attenuates pathological cardiac hypertrophy and apoptosis in high-fat diet fed mice. J Ethnopharmacol. 2016; 192:170-77. https://doi. org/10.1016/j.jep.2016.07.018.

8. Mishra SK, Tripathi S, Shukla A, Oh SH, Kim HM. Andrographolide and analogues in cancer prevention. Front Biosci (Elite Ed). 2015; 7:255-66. https://doi.org/10.2741/e732.

9. Wong SY, Tan MG, Wong PT, Herr DR, Lai MK. Andrographolide induces Nrf2 and heme oxygenase 1 in astrocytes by activating p38 MAPK and ERK. J Neuroinflammation. 2016; 13:251. https://doi.org/10.1186/ s12974-016-0723-3.

10. Cheung HY, Cheung SH, Li J, Cheung CS, Lai WP, Fong WF, Leung FM. Andrographolide isolated from Andrographis paniculata induces cell cycle arrest and mitochondrial-mediated apoptosis in human leukemic HL-60 cells. Planta Med. 2005; 71:1106-11. https://doi. org/10.1055/s-2005-873128.

11. Rajagopal S, Kumar RA, Deevi DS, Satyanarayana C, Rajagopalan R. Andrographolide, a potential cancer 
therapeutic agent isolated from Andrographis paniculata. J Exp Ther Oncol. 2003; 3:147-58. https://doi. org/10.1046/j.1359-4117.2003.01090.x.

12. Khamphaya $T$, Chansela $P$, Piyachaturawat $P$, Suksamrarn A, Nathanson MH, Weerachayaphorn J. Effects of andrographolide on intrahepatic cholestasis induced by alpha-naphthylisothiocyanate in rats. Eur J Pharmacol. 2016; 789:254-64. https://doi.org/10.1016/j.ejphar.2016.07.032.

13. Sheeja K, Shihab PK, Kuttan G. Antioxidant and antiinflammatory activities of the plant Andrographis paniculata Nees. Immunopharmacol Immunotoxicol. 2006; 28:129-40. https://doi.org/10.1080/08923970600626007.

14. Mittal SP, Khole S, Jagadish N, Ghosh D, Gadgil V, Sinkar V, Ghaskadbi SS. Andrographolide protects liver cells from $\mathrm{H} 2 \mathrm{O} 2$ induced cell death by upregulation of Nrf-2/ HO-1 mediated via adenosine A2a receptor signalling. Biochim Biophys Acta. 2016; 1860:2377-90. https://doi. org/10.1016/j.bbagen.2016.07.005.

15. Singha PK, Roy S, Dey S. Antimicrobial activity of Andrographis paniculata. Fitoterapia. 2003; 74:692-94. https://doi.org/10.1016/S0367-326X(03)00159-X.

16. Kumar RA, Sridevi K, Kumar NV, Nanduri S, Rajagopal S. Anticancer and immunostimulatory compounds from Andrographis paniculata. J Ethnopharmacol. 2004; 92: 291-95. https://doi.org/10.1016/j.jep.2004.03.004.

17. Kim YS, Milner JA. Targets for indole-3-carbinol in cancer prevention. J Nutr Biochem. 2005; 16:65-73. https://doi. org/10.1016/j.jnutbio.2004.10.007.

18. Zhou J, Zhang S, Ong CN, Shen HM. Critical role of proapoptotic Bcl-2 family members in andrographolide-induced apoptosis in human cancer cells. Biochem Pharmacol. 2006; 72:132-44. https://doi.org/10.1016/j.bcp.2006.04.019.

19. Kumar D, Kumar S, Gorain M, Tomar D, Patil HS, Radharani NN, Kumar TV, Patil TV, Thulasiram HV, Kundu GC. Notch1-MAPK Signaling Axis Regulates CD133+ Cancer Stem Cell-Mediated Melanoma Growth and Angiogenesis. J Invest Dermatol. 2016; 136:2462-74. https://doi.org/10.1016/j.jid.2016.07.024.

20. Shen K, Ji L, Lu B, Xu C, Gong C, Morahan G, Wang Z. Andrographolide inhibits tumor angiogenesis via blocking VEGFA/VEGFR2-MAPKs signaling cascade. Chem Biol Interact. 2014; 218:99-106. https://doi.org/10.1016/j. cbi.2014.04.020.

21. Shang HS, Chang CH, Chou YR, Yeh MY, Au MK, Lu HF, Chu YL, Chou HM, Chou HC, Shih YL, Chung JG. Curcumin causes DNA damage and affects associated protein expression in HeLa human cervical cancer cells. Oncol Rep. 2016; 36:2207-15. https://doi.org/10.3892/or.2016.5002.

22. Ting CY, Wang HE, Yu CC, Liu HC, Liu YC, Chiang IT. Curcumin Triggers DNA Damage and Inhibits Expression of DNA Repair Proteins in Human Lung Cancer Cells. Anticancer Res. 2015; 35:3867-73.

23. Isaacs JT, Hukku B. Nonrandom involvement of chromosome 4 in the progression of rat prostatic cancer.
Prostate. 1988; 13:165-88. https://doi.org/10.1002/ pros.2990130208.

24. Matthaios D, Foukas PG, Kefala M, Hountis P, Trypsianis G, Panayiotides IG, Chatzaki E, Pantelidaki E, Bouros D, Karakitsos P, Kakolyris S. $\gamma-\mathrm{H} 2 \mathrm{AX}$ expression detected by immunohistochemistry correlates with prognosis in early operable non-small cell lung cancer. Onco Targets Ther. 2012; 5:309-14. https://doi.org/10.2147/OTT.S36995.

25. Shi MD, Lin HH, Lee YC, Chao JK, Lin RA, Chen JH. Inhibition of cell-cycle progression in human colorectal carcinoma Lovo cells by andrographolide. Chem Biol Interact. 2008; 174:201-10. https://doi.org/10.1016/j.cbi.2008.06.006.

26. Satyanarayana C, Deevi DS, Rajagopalan R, Srinivas N, Rajagopal S. DRF 3188 a novel semi-synthetic analog of andrographolide: cellular response to MCF 7 breast cancer cells. BMC Cancer. 2004; 4:26. https://doi. org/10.1186/1471-2407-4-26.

27. Kayastha F, Madhu H, Vasavada A, Johar K. Andrographolide reduces proliferation and migration of lens epithelial cells by modulating PI3K/Akt pathway. Exp Eye Res. 2014; 128:23-26. https://doi.org/10.1016/j. exer.2014.09.002.

28. Mir H, Kapur N, Singh R, Sonpavde G, Lillard JW Jr, Singh $\mathrm{S}$. Andrographolide inhibits prostate cancer by targeting cell cycle regulators, CXCR3 and CXCR7 chemokine receptors. Cell Cycle. 2016; 15:819-26. https://doi.org/10.1080/15384 101.2016.1148836.

29. Chun JY, Tummala R, Nadiminty N, Lou W, Liu C, Yang J, Evans CP, Zhou Q, Gao AC. Andrographolide, an herbal medicine, inhibits interleukin-6 expression and suppresses prostate cancer cell growth. Genes Cancer. 2010; 1:868-76. https://doi.org/10.1177/1947601910383416.

30. Pan MH, Ghai G, Ho CT. Food bioactives, apoptosis, and cancer. Mol Nutr Food Res. 2008; 52:43-52. https://doi. org/10.1002/mnfr.200700380.

31. Wang S, El-Deiry WS. TRAIL and apoptosis induction by TNF-family death receptors. Oncogene. 2003; 22:8628-33. https://doi.org/10.1038/sj.onc.1207232.

32. Mirochnik Y, Veliceasa D, Williams L, Maxwell K, Yemelyanov A, Budunova I, Volpert OV. Androgen receptor drives cellular senescence. PLoS One. 2012; 7:e31052. https://doi.org/10.1371/journal.pone.0031052.

33. Geethangili M, Rao YK, Fang SH, Tzeng YM. Cytotoxic constituents from Andrographis paniculata induce cell cycle arrest in jurkat cells. Phytother Res. 2008; 22:1336-41. https://doi.org/10.1002/ptr.2493.

34. Wang Q, Su L, Liu N, Zhang L, Xu W, Fang H. Cyclin dependent kinase 1 inhibitors: a review of recent progress. Curr Med Chem. 2011; 18:2025-43. https://doi. org/10.2174/092986711795590110.

35. Gulappa T, Reddy RS, Suman S, Nyakeriga AM, Damodaran C. Molecular interplay between cdk4 and p21 dictates G0/G1 cell cycle arrest in prostate cancer cells. Cancer Lett. 2013; 337:177-83. https://doi.org/10.1016/j.canlet.2013.05.014. 
36. Kumar S, Patil HS, Sharma P, Kumar D, Dasari S, Puranik VG, Thulasiram HV, Kundu GC. Andrographolide inhibits osteopontin expression and breast tumor growth through down regulation of PI3 kinase/Akt signaling pathway. Curr Mol Med. 2012; 12:952-66. https://doi. org/10.2174/156652412802480826.

37. Zhang M, Xue E, Shao W. Andrographolide promotes vincristine-induced SK-NEP-1 tumor cell death via PI3KAKT-p53 signaling pathway. Drug Des Devel Ther. 2016; 10:3143-52. https://doi.org/10.2147/DDDT.S113838.

38. Zhang QQ, Zhou DL, Ding Y, Liu HY, Lei Y, Fang HY, Gu QL, He XD, Qi CL, Yang Y, Lan T, Li JC, Gong P, et al. Andrographolide inhibits melanoma tumor growth by inactivating the TLR4/NF- $\mathrm{BB}$ signaling pathway. Melanoma Res. 2014; 24:545-55. https://doi.org/10.1097/ CMR.0000000000000117.

39. Lai YH, Yu SL, Chen HY, Wang CC, Chen HW, Chen JJ. The HLJ1-targeting drug screening identified Chinese herb andrographolide that can suppress tumour growth and invasion in non-small-cell lung cancer. Carcinogenesis. 2013; 34:1069-80. https://doi.org/10.1093/carcin/bgt005.

40. Liu P, Wang X, Hu CH, Hu TH. Bioinformatics analysis with graph-based clustering to detect gastric cancer-related pathways. Genet Mol Res. 2012; 11:3497-504. https://doi. org/10.4238/2012.September.26.5.

41. Hansmann F, Herder V, Kalkuhl A, Haist V, Zhang N, Schaudien D, Deschl U, Baumgärtner W, Ulrich R. Matrix metalloproteinase-12 deficiency ameliorates the clinical course and demyelination in Theiler's murine encephalomyelitis. Acta Neuropathol. 2012; 124:127-42. https://doi.org/10.1007/s00401-012-0942-3.

42. Griner SE, Joshi JP, Nahta R. Growth differentiation factor 15 stimulates rapamycin-sensitive ovarian cancer cell growth and invasion. Biochem Pharmacol. 2013; 85:46-58. https:// doi.org/10.1016/j.bcp.2012.10.007.

43. McCawley LJ, Matrisian LM. Matrix metalloproteinases: they're not just for matrix anymore! Curr Opin Cell Biol. 2001; 13:534-40. https://doi.org/10.1016/ S0955-0674(00)00248-9.

44. Zou W, Ma X, Hua W, Chen B, Huang Y, Wang D, Cai G. BRIP1 inhibits the tumorigenic properties of cervical cancer by regulating RhoA GTPase activity. Oncol Lett. 2016; 11:551-58. https://doi.org/10.3892/ol.2015.3963.

45. Rafnar T, Gudbjartsson DF, Sulem P, Jonasdottir A, Sigurdsson A, Jonasdottir A, Besenbacher S, Lundin P, Stacey SN, Gudmundsson J, Magnusson OT, le Roux L, Orlygsdottir G, et al. Mutations in BRIP1 confer high risk of ovarian cancer. Nat Genet. 2011; 43:1104-07. https://doi. org/10.1038/ng.955.

46. Song H, Ramus SJ, Kjaer SK, Hogdall E, Dicioccio RA, Whittemore AS, McGuire V, Hogdall C, Jacobs IJ, Easton DF, Ponder BA, Dunning AM, Gayther SA, Pharoah PD. Tagging single nucleotide polymorphisms in the BRIP1 gene and susceptibility to breast and ovarian cancer. PLoS One. 2007; 2:e268. https://doi.org/10.1371/journal.pone.0000268.
47. Levitus M, Waisfisz Q, Godthelp BC, de Vries Y, Hussain S, Wiegant WW, Elghalbzouri-Maghrani E, Steltenpool J, Rooimans MA, Pals G, Arwert F, Mathew CG, Zdzienicka MZ, et al. The DNA helicase BRIP1 is defective in Fanconi anemia complementation group J. Nat Genet. 2005; 37 : 934-35. https://doi.org/10.1038/ng1625.

48. Narayan G, Arias-Pulido H, Nandula SV, Basso K, Sugirtharaj DD, Vargas H, Mansukhani M, Villella J, Meyer L, Schneider A, Gissmann L, Dürst M, Pothuri B, Murty VV. Promoter hypermethylation of FANCF: disruption of Fanconi Anemia-BRCA pathway in cervical cancer. Cancer Res. 2004; 64:2994-97. https://doi.org/10.1158/0008-5472. CAN-04-0245.

49. Gudmundsdottir K, Ashworth A. The roles of BRCA1 and BRCA2 and associated proteins in the maintenance of genomic stability. Oncogene. 2006; 25:5864-74. https://doi. org/10.1038/sj.onc.1209874.

50. Venkitaraman AR. Cancer susceptibility and the functions of BRCA1 and BRCA2. Cell. 2002; 108:171-82. https://doi. org/10.1016/S0092-8674(02)00615-3.

51. Boulton SJ. Cellular functions of the BRCA tumoursuppressor proteins. Biochem Soc Trans. 2006; 34:633-45. https://doi.org/10.1042/BST0340633.

52. Geißler AL, Geißler M, Kottmann D, Lutz L, Fichter CD, Fritsch R, Weddeling B, Makowiec F, Werner M, Lassmann S. ATM mutations and E-cadherin expression define sensitivity to EGFR-targeted therapy in colorectal cancer. Oncotarget. 2017; 8:17164-90. https://doi.org/10.18632/ oncotarget.15211.

53. Rosinha A, Assis J, Dias F, Nogueira A, Pereira D, Maurício J, Teixeira AL, Medeiros R. DNA repair system and renal cell carcinoma prognosis: under the influence of NBS1. Med Oncol. 2015; 32:255. https://doi.org/10.1007/ s12032-015-0701-0.

54. Hann DM, Baker F, Roberts CS, Witt C, McDonald J, Livingston M, Ruiterman J, Ampela R, Crammer C, Kaw O. Use of complementary therapies among breast and prostate cancer patients during treatment: a multisite study. Integr Cancer Ther. 2005; 4:294-300. https://doi. org/10.1177/1534735405282109.

55. Hanada K, Hickson ID. Molecular genetics of RecQ helicase disorders. Cell Mol Life Sci. 2007; 64:2306-22. https://doi. org/10.1007/s00018-007-7121-z.

56. Park JY, Zhang F, Andreassen PR. PALB2: the hub of a network of tumor suppressors involved in DNA damage responses. Biochim Biophys Acta. 2014; 1846:263-75. https://doi.org/10.1016/j.bbcan.2014.06.003.

57. Mariotti LG, Pirovano G, Savage KI, Ghita M, Ottolenghi A, Prise KM, Schettino G. Use of the $\gamma-\mathrm{H} 2 \mathrm{AX}$ assay to investigate DNA repair dynamics following multiple radiation exposures. PLoS One. 2013; 8:e79541. https://doi. org/10.1371/journal.pone.0079541.

58. Podhorecka M, Skladanowski A, Bozko P. H2AX Phosphorylation: Its Role in DNA Damage Response and 
Cancer Therapy. J Nucleic Acids. 2010; 2010:920161. https://doi.org/10.4061/2010/920161.

59. El-Deiry WS. Insights into cancer therapeutic design based on p53 and TRAIL receptor signaling. Cell Death Differ. 2001; 8:1066-75. https://doi.org/10.1038/sj.cdd.4400943.

60. Kastan MB, Lim DS. The many substrates and functions of ATM. Nat Rev Mol Cell Biol. 2000; 1:179-86. https://doi. org/10.1038/35043058.

61. Chappell WH, Lehmann BD, Terrian DM, Abrams SL, Steelman LS, McCubrey JA. p53 expression controls prostate cancer sensitivity to chemotherapy and the MDM2 inhibitor Nutlin-3. Cell Cycle. 2012; 11:4579-88. https://doi. org/10.4161/cc.22852.

62. Brazma A, Hingamp P, Quackenbush J, Sherlock G, Spellman P, Stoeckert C, Aach J, Ansorge W, Ball CA, Causton HC, Gaasterland T, Glenisson P, Holstege FC, et al. Minimum information about a microarray experiment (MIAME)-toward standards for microarray data. Nat Genet. 2001; 29:365-71. https://doi.org/10.1038/ng1201-365. 